NASA/TM-2010-216781

\title{
Three-Body Abrasion Testing Using Lunar Dust Simulants to Evaluate Surface System Materials
}

Ryan L. Kobrick

University of Colorado at Boulder, Boulder, Colorado

Kenneth G. Budinski

Bud Labs, Inc., Rochester, New York

Kenneth W. Street, Jr.

Glenn Research Center, Cleveland, Ohio

David M. Klaus

University of Colorado at Boulder, Boulder, Colorado 


\section{NASA STI Program . . . in Profile}

Since its founding, NASA has been dedicated to the advancement of aeronautics and space science. The NASA Scientific and Technical Information (STI) program plays a key part in helping NASA maintain this important role.

The NASA STI Program operates under the auspices of the Agency Chief Information Officer. It collects, organizes, provides for archiving, and disseminates NASA's STI. The NASA STI program provides access to the NASA Aeronautics and Space Database and its public interface, the NASA Technical Reports Server, thus providing one of the largest collections of aeronautical and space science STI in the world. Results are published in both non-NASA channels and by NASA in the NASA STI Report Series, which includes the following report types:

- TECHNICAL PUBLICATION. Reports of completed research or a major significant phase of research that present the results of NASA programs and include extensive data or theoretical analysis. Includes compilations of significant scientific and technical data and information deemed to be of continuing reference value. NASA counterpart of peer-reviewed formal professional papers but has less stringent limitations on manuscript length and extent of graphic presentations.

- TECHNICAL MEMORANDUM. Scientific and technical findings that are preliminary or of specialized interest, e.g., quick release reports, working papers, and bibliographies that contain minimal annotation. Does not contain extensive analysis.

- CONTRACTOR REPORT. Scientific and technical findings by NASA-sponsored contractors and grantees.
- CONFERENCE PUBLICATION. Collected papers from scientific and technical conferences, symposia, seminars, or other meetings sponsored or cosponsored by NASA.

- SPECIAL PUBLICATION. Scientific, technical, or historical information from NASA programs, projects, and missions, often concerned with subjects having substantial public interest.

- TECHNICAL TRANSLATION. Englishlanguage translations of foreign scientific and technical material pertinent to NASA's mission.

Specialized services also include creating custom thesauri, building customized databases, organizing and publishing research results.

For more information about the NASA STI program, see the following:

- Access the NASA STI program home page at http://www.sti.nasa.gov

- E-mail your question via the Internet to help@ sti.nasa.gov

- Fax your question to the NASA STI Help Desk at $443-757-5803$

- Telephone the NASA STI Help Desk at 443-757-5802

- Write to: NASA Center for AeroSpace Information (CASI) 7115 Standard Drive Hanover, MD 21076-1320 
NASA/TM-2010-216781

N.S:A

Three-Body Abrasion Testing Using Lunar Dust Simulants to Evaluate Surface System Materials

Ryan L. Kobrick

University of Colorado at Boulder, Boulder, Colorado

Kenneth G. Budinski

Bud Labs, Inc., Rochester, New York

Kenneth W. Street, Jr.

Glenn Research Center, Cleveland, Ohio

David M. Klaus

University of Colorado at Boulder, Boulder, Colorado

Prepared for the

40th International Conference on Environmental Systems

cosponsored by the AIAA, AICHE, ASME, SAE Environmental Systems Committee, and ICES International Committee

Barcelona, Spain, July 11-15, 2010

National Aeronautics and

Space Administration

Glenn Research Center

Cleveland, Ohio 44135 


\section{Acknowledgments}

This research was supported by a NASA Graduate Student Researchers Program (GSRP) grant (NNX07AR55H) provided by the Dust Management Project, under the Exploration Technology Development Program at the Glenn Research Center (GRC). Test equipment and support were provided by Bud Labs, Inc. and simulants were provided by NASA GRC. Additional support was provided by BioServe Space Technologies at the University of Colorado at Boulder and the Achievement Rewards for College Scientists (ARCS) Foundation, Inc.

Trade names and trademarks are used in this report for identification only. Their usage does not constitute an official endorsement, either expressed or implied, by the National Aeronautics and Space Administration.

Level of Review: This material has been technically reviewed by technical management.

Available from

NASA Center for Aerospace Information 7115 Standard Drive

Hanover, MD 21076-1320
National Technical Information Service 5301 Shawnee Road Alexandria, VA 22312

Available electronically at http://gltrs.grc.nasa.gov 


\title{
Three-Body Abrasion Testing Using Lunar Dust Simulants to Evaluate Surface System Materials
}

\author{
Ryan L. Kobrick \\ University of Colorado at Boulder \\ Boulder, Colorado 80309 \\ Kenneth G. Budinski \\ Bud Labs, Inc. \\ Rochester, New York 14615 \\ Kenneth W. Street, Jr. \\ National Aeronautics and Space Administration \\ Glenn Research Center \\ Cleveland, Ohio 44135 \\ David M. Klaus \\ University of Colorado at Boulder \\ Boulder, Colorado 80309
}

\begin{abstract}
Numerous unexpected operational issues relating to the abrasive nature of lunar dust, such as scratched visors and spacesuit pressure seal leaks, were encountered during the Apollo missions. To avoid reoccurrence of these unexpected detrimental equipment problems on future missions to the Moon, a series of two- and three-body abrasion tests were developed and conducted in order to begin rigorously characterizing the effect of lunar dust abrasiveness on candidate surface system materials. Two-body scratch tests were initially performed to examine fundamental interactions of a single particle on a flat surface. These simple and robust tests were used to establish standardized measurement techniques for quantifying controlled volumetric wear. Subsequent efforts described in the paper involved three-body abrasion testing designed to be more representative of actual lunar interactions. For these tests, a new tribotester was developed to expose samples to a variety of industrial abrasives and lunar simulants. The work discussed in this paper describes the three-body hardware setup consisting of a rotating rubber wheel that applies a load on a specimen as a loose abrasive is fed into the system. The test methodology is based on ASTM International (ASTM) B611, except it does not mix water with the abrasive. All tests were run under identical conditions. Abraded material specimens included poly(methyl methacrylate) (PMMA), hardened 1045 steel, 6061-T6 aluminum (Al) and 1018 steel. Abrasives included lunar mare simulant JSC-1A-F (nominal size distribution), sieved JSC-1A-F ( $<25 \mu \mathrm{m}$ particle diameter), lunar highland simulant NU-LHT-2M, alumina (average diameter of $50 \mu \mathrm{m}$ used per ASTM G76), and silica (50/70 mesh used per ASTM G65). The measured mass loss from each specimen was converted using standard densities to determine total wear volume in $\mathrm{cm}^{3}$. Abrasion was dominated by the alumina and the simulants were only similar to the silica (i.e., sand) on the softer materials of aluminum and PMMA. The nominal JSC-1A-F consistently showed more abrasion wear than the sieved version of the simulant. The lunar dust displayed abrasivity to all of the test materials, which are likely to be used in lunar landing equipment. Based on this test experience and pilot results obtained, recommendations are made for systematic abrasion testing of candidate materials intended for use in lunar exploration systems and in other environments with similar dust challenges.
\end{abstract}




\section{Introduction}

Numerous unexpected operational issues relating to the abrasive nature of lunar dust were encountered during the Apollo missions. Issues recorded by astronauts on lunar extravehicular activity (EVA) were catalogued by Gaier (Ref. 1) and included abrasion on Apollo spacesuits leading to scratches and wear affecting visibility and pressure retention. The resultant fine-grained and highly angular shapes of lunar dust particles have been attributed to the continuous micrometeorite bombardment of the Moon and a lack of mechanical weathering, consequently making them especially abrasive (Refs. 2 and 3). Fine dust particles in this context are typically characterized by their size range of $<1$ to $50 \mu \mathrm{m}$ (Refs. 4 and 5). Although specific definitions between groups vary, on average, researchers refer to particles with diameters less than $20 \mu \mathrm{m}$ as "dust" (Refs. 6 and 7).

The National Aeronautics and Space Administration (NASA) Dust Management Project (DMP) has identified key physical properties of interest to the lunar science community. Abrasion's importance for study was ranked as 'high' for future exploration missions because it affects any space system component that comes into contact with dust, especially having moving parts and/or has a seal. The DMP was created in the Exploration Technology Development Program (ETDP) at NASA following the results and assessment of the Exploration Systems Architecture Study (ESAS). One goal of the research being conducted within the DMP is to develop recommendations and standard testing protocols for evaluating the impact of lunar dust abrasion on proposed surface system materials and operations. Both two-body and three-body abrasion modes are currently being investigated for future NASA testing of lunar equipment in relevant environments using abrasives that parallel actual regolith, known as lunar dust simulants.

To avoid reoccurrence of detrimental equipment abrasion problems noted during Apollo, future lunar surface systems (LSS) used in missions to the Moon can be designed to take into account expected operational wear. To rigorously characterize the effect of lunar dust abrasiveness on candidate materials, a series of two- and three-body abrasion tests have been developed and conducted. Two-body scratch tests were initially performed to examine fundamental interactions of a single particle on a flat surface (Refs. 6 and 7). These simple and robust tests were used to establish standardized measurement techniques for quantifying controlled volumetric wear (Refs. 8 and 9). Subsequent testing involved a three-body abrasion technique designed to be more representative of actual operational interactions. For these tests, a new tribotester was developed to expose samples to a variety of typical abrasives and the lunar simulants JSC-1A-F, representative of the lunar mare region, and NU-LHT-2M, representative of the lunar highland region (both are based on the average chemical composition of Apollo samples). This paper discusses the apparatus, methodology and results obtained from initial testing.

\section{New Test Methodology}

The initial two-body abrasion baseline laid the foundation for conducting the more representative three-body tests. Instead of a single pass scratch, three-body abrasion better simulates the lifetime of a material by quantifying material removal in a set amount of time based on intended operational interactions. This test method is a derivative of the ASTM International (ASTM) B611 Standard that allows use of custom abrasives, i.e., lunar stimulants (Ref. 10). The test specimen is cleaned and weighed three times to determine the initial mass. From 20 to 80 grams of abrasive is fed onto the rubber wheel (as indicated in Figure 1) during the entire test time. The specimen is at the bottom of a vessel that holds loose abrasive and the rubber wheel forces the abrasive against the horizontal counterface (see Figure 1 for configuration). Mass change is used as the test metric. The tester is shut down after 450 revolutions $(170 \mathrm{~m})$. The test specimens are washed in water and Windex (S. C. Johnson \& Son, Inc.) after testing and dried before reweighing (see Figure 2). The specimens are again weighed three times for a final mass average. Fresh abrasive was used for each test. 


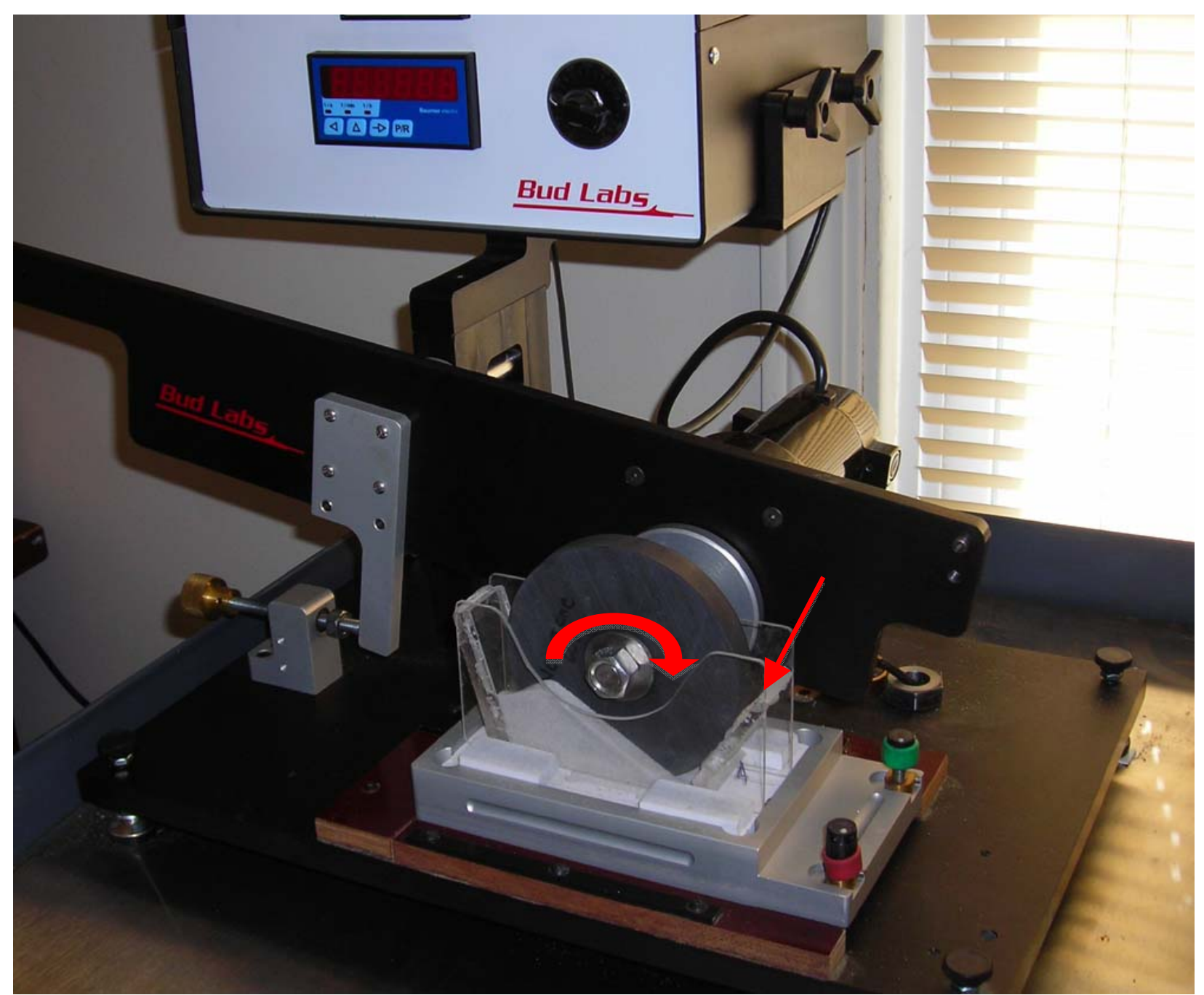

Figure 1.-Three-body abrasion tester (rotation direction indicated with curved arrow) with abrasive entry point on right side (indicated with straight arrow). The specimen sits at the bottom of the rotation wheel.

The test employed uses the same concept as ASTM B611 except that the testing equipment (Bud Labs, Rochester, NY) uses a rubber wheel and no water, just a dry abrasive, which is more applicable for Moon, Mars or other celestial body abrasion environments. The test is not a standard yet, as methods of feeding dust into the system are still being evaluated. The abrasion tester includes a 60 Shore A Neoprene wheel $(12.7 \mathrm{~mm}$ wheel width, $109 \mathrm{~mm}$ diameter), with velocity of $0.17 \mathrm{~m} / \mathrm{s}(30 \mathrm{rpm})$ and a force on the specimen of $55 \mathrm{~N}(12.3 \mathrm{lb})$.

Abrasives and material specimens used are summarized in Table 1 with number of tests conducted. Abrasives included: JSC-1A-F (nominal size distribution); sieved JSC-1A-F (less than $25 \mu \mathrm{m}$ particle diameter prepared by NASA Glenn Research Center using a mechanical sieve); alumina (50 $\mu$ m average particle diameter); and sand with AGSCO AFS 50/70 mesh (200 $\mu \mathrm{m}$ average diameter). A chemical or sieve analysis is not conducted on the later two abrasives because both are ASTM test standard abrasives and shipped as such. The sand is used in ASTM G65 and the alumina is used in ASTM G76 (Refs. 11 and 12). Material specimens that were abraded included: 6061-T6 aluminum (Al); 1018 steel (hardness of $60 \mathrm{HRB}$ ); 1045 steel (hardness of $50 \mathrm{HRC}$ ); and poly(methyl methacrylate) (PMMA). 
TABLE 1.-THREE-BODY ABRASION TEST SUMMARY WITH NEW TRIBOTESTER

Number of Abrasive Tests

\begin{tabular}{lccccc} 
Material & JSC-1A-F & JSC-1A-F $<25$ um & Alumina & Silica (Sand) & NU-LHT-2M \\
\hline 6061-T6 Al & 3 & 3 & 4 & 4 & 3 \\
1018 Steel & 3 & 3 & 4 & 4 & 3 \\
1045 Steel & 3 & 3 & 4 & 4 & 3 \\
PMMA & 3 & 3 & 4 & 4 & 3
\end{tabular}

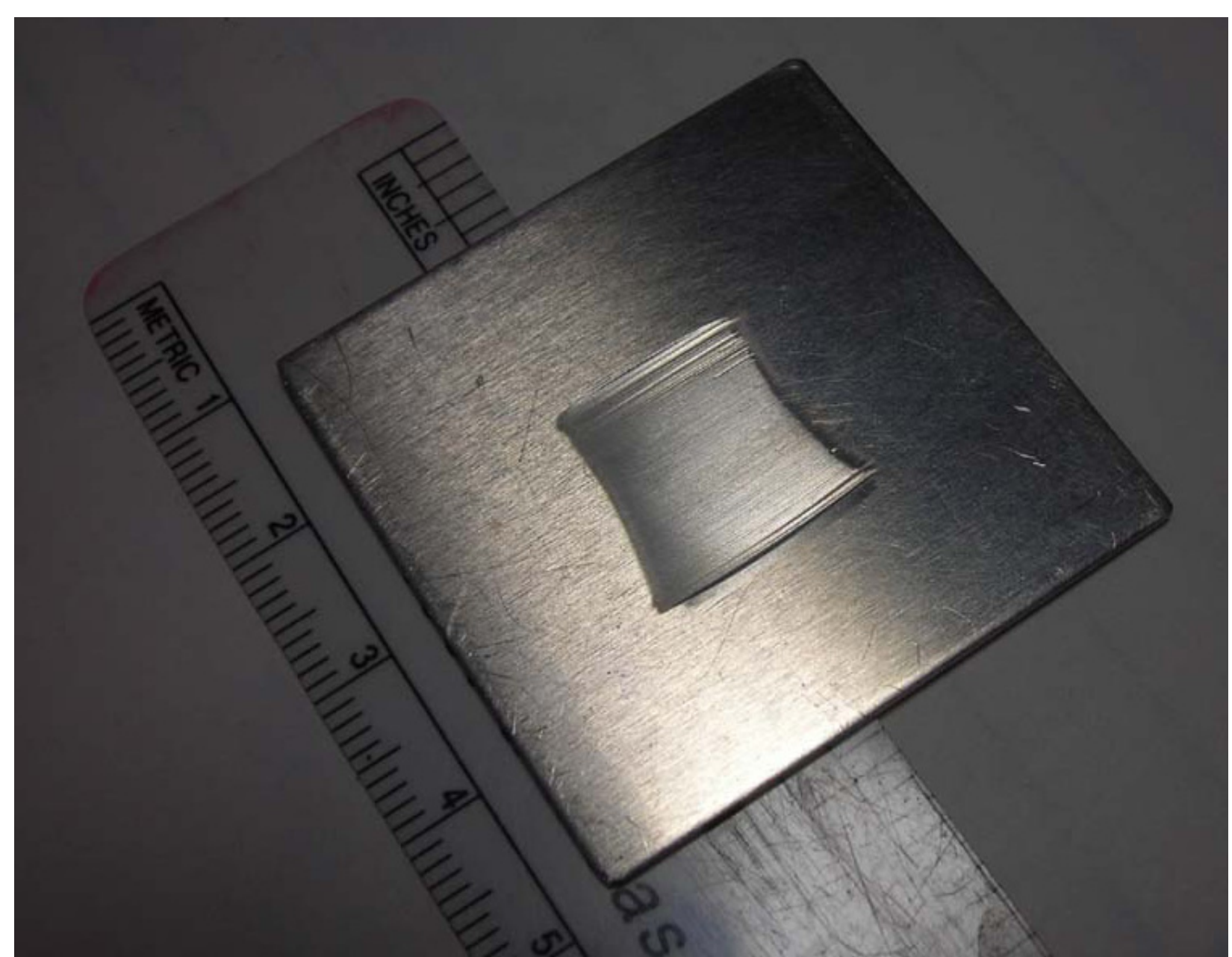

Figure 2.--Image of aluminum specimen after being abraded by alumina.

\section{Results}

The results (summarized in Appendix A) are graphically presented in Figure 3 and Figure 4 as wear volume loss in $\mathrm{cm}^{3}$ after conversion using material densities (Ref. 13). Figure 3 represents the PMMA wear volumes from various simulants and Figure 4 represents the metal specimens wear volumes. The discussion following the results includes qualitative observations inferred from the data. Further tests would have to be repeated in multiple labs to establish quantitative statistical significance. The test materials selected represent the range of materials likely to be used in lunar landing equipment or other spacecraft missions that will voyage to planetary or asteroid surfaces. 


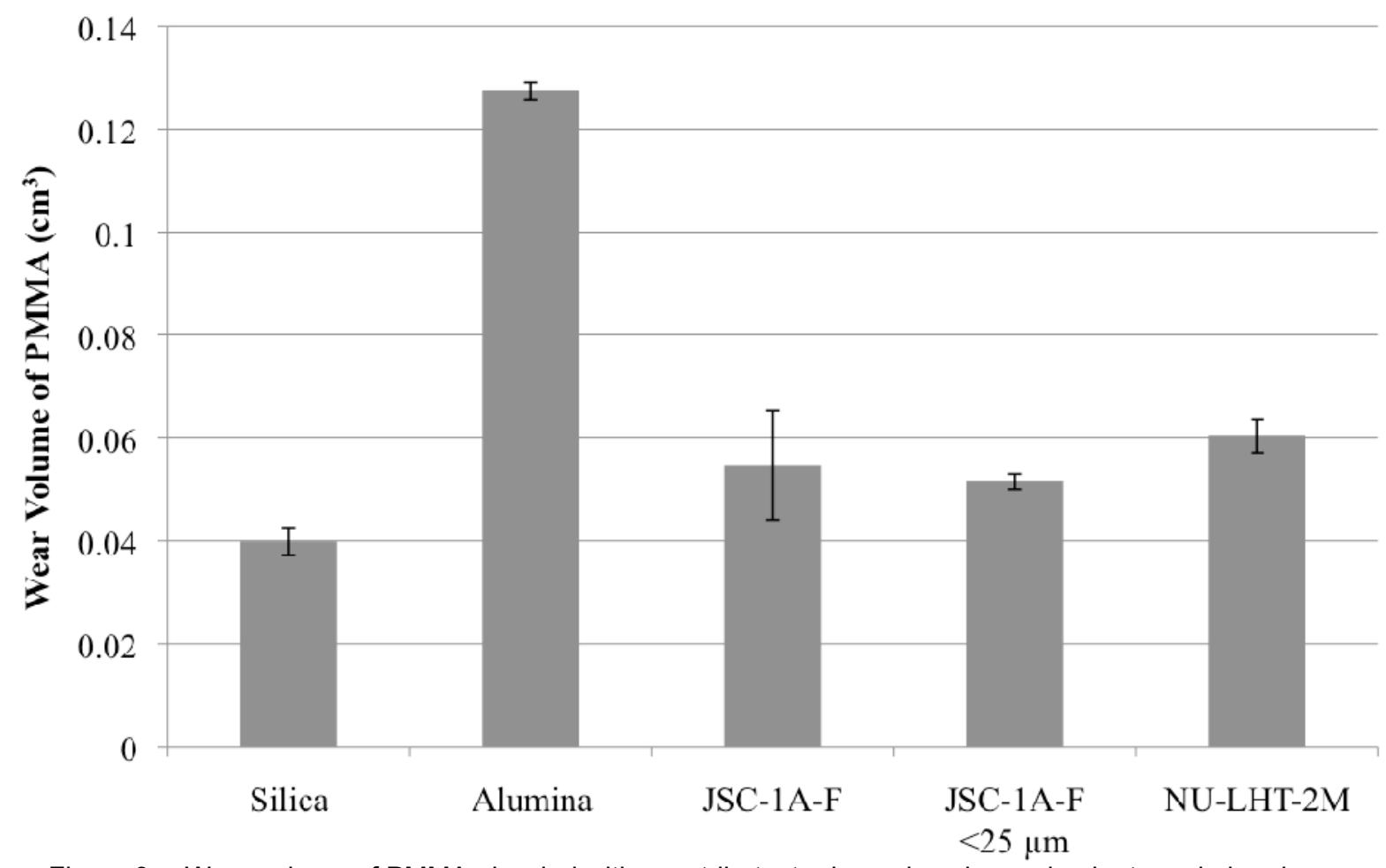

Figure 3.-Wear volume of PMMA abraded with new tribotester by various lunar simulants and abrasives.

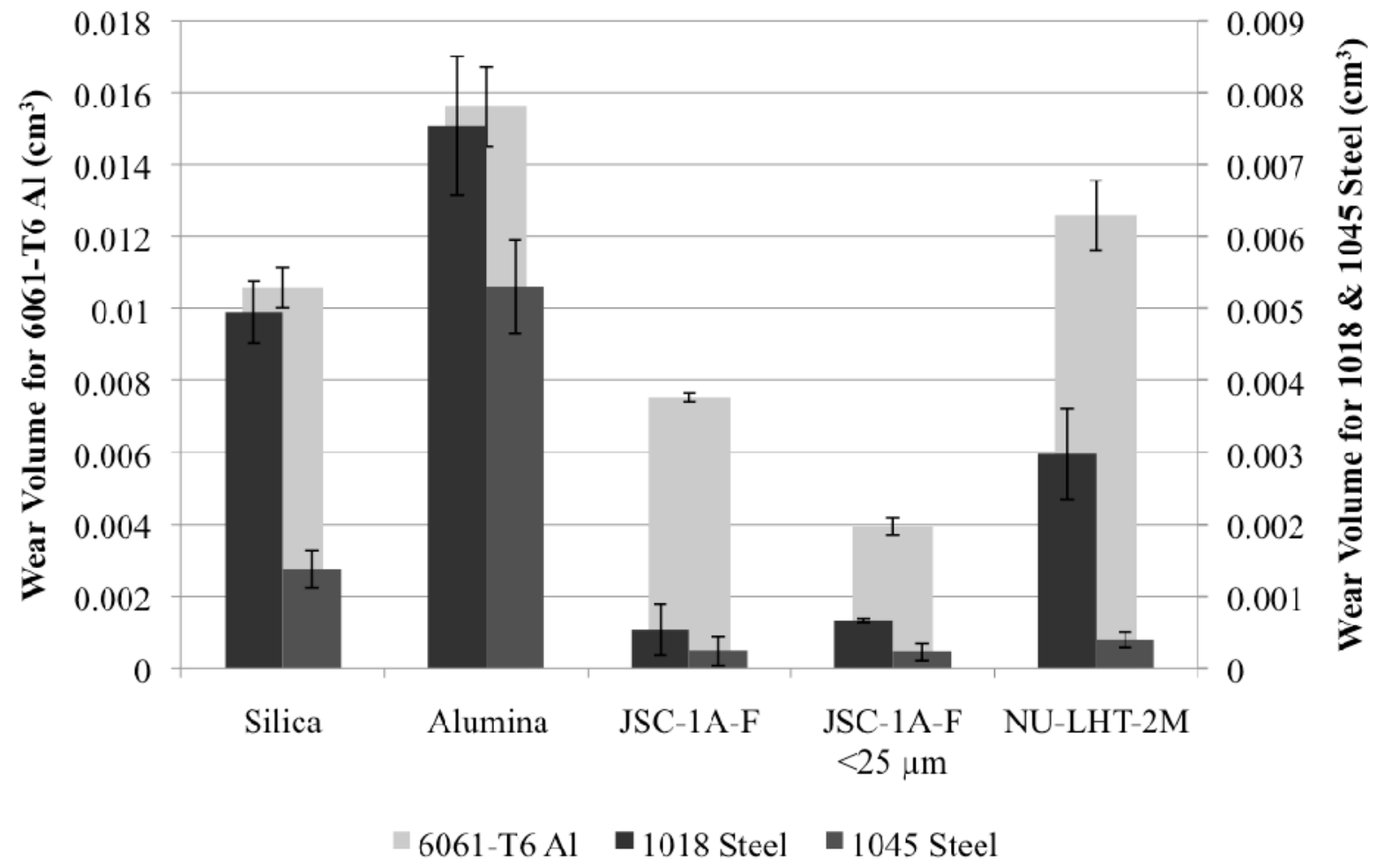

Figure 4.-Wear volume of metals abraded with new tribotester by various lunar simulants and abrasives. 


\section{Discussion}

Based on the experience and pilot results obtained from this testing, lunar dust simulants can be expected to produce a range of wear effects on various materials. The data indicate that lunar dust simulants have comparable abrasivity to silica on the softer test materials only (Al and PMMA). The tests results showed similar trends for wear volume in the different materials. Alumina powder dominated abrasion on all materials, resulting in the most volume removed. In general, steels showed good resistance to abrasion against the lunar simulants, aluminum is prone to abrasion by the simulants, and PMMA is very prone to abrasion by simulants.

The JSC-1A-F nominal particle size distribution produced more wear than the sieved version of the abrasive. This size difference may or may not be the reason for the difference in values obtained since the mineralogy is not uniformly distributed within the simulant by size fraction. This means that the larger particles removed by sieving might be harder minerals. Most of the abrasives were in the 25 to $100 \mu \mathrm{m}$ range except the silica, which was closer to $200 \mu \mathrm{m}$. It was observed in the NU-LHT-2M simulant that there were large $500 \mu \mathrm{m}$ pieces that would stall at the wheel's base upon contact, and when they did, a distinctive "crunch" was heard. Smaller particles are likely to polish materials, while the larger particulates may be causing the most wear. Therefore, selection of appropriate abrasive particle size and distribution will be critical for fully characterizing wear interactions using this device.

The simulants available are representative of the two main lunar regions (mare and highlands) so do not represent the full diversity of the lunar terrain. Further, recently available information by Cole et al. (Ref. 14) on the strength of lunar regolith grains as compared to terrestrial materials of similar composition has demonstrated that lunar plagioclase grains can have two to three times less mechanical strength than terrestrial material when compressed. Cole et al. paper clarifies why the terrestrial counterparts are considerably more robust - the lunar grains appear to be composed of much smaller fragments fused or sintered together. This structure is considerably weaker at the fragment boundaries than the internal crystal energies holding mineral crystals grains together thus leading to enhanced friability. If actual lunar grains were applied to the testing procedure described in Section II of this paper, one would expect to see considerably less damage due to the polishing action of the fine fragments as they are released by mechanical crushing. This means that laboratory tests should be conducted with abrasives that are specific to the intended location of future missions. A similar approach can be used to develop testing protocols for exploration of Mars, asteroids or other planetary surfaces.

An alternative to location specific abrasive selection would be to over design a system to take into account a worst-case wear scenario. For example, pure alumina could be used as a single test abrasive in place of specific lunar simulants if it is consistently shown to produce the most significant abrasive wear in future tests. This approach would come at a mass penalty, but might help with risk assessment or in establishing engineering design safety factors. Ultimately, using systematic abrasion testing and measurements can aid in material selection for lunar surface systems, as well as for other spaceflight or terrestrial environments with similar dust challenges.

\section{Conclusions and Recommendations}

The new tribotester demonstrated that well-controlled data could be obtained using a variety of dry abrasives and test materials. This device provides a versatile means of conducting material abrasion testing recommended for planetary exploration because of the flexibility to systematically change abrasive variables such as grain size. Future upgrades to the simulations could add control of humidity, temperature, and pressure, as needed. This test method is simple and inexpensive, making it attractive to the space engineering design community to either adopt directly or contract out to a lab for analysis. Future work is planned to address the effects of varying the alumina average grain size. Other suggested tests include varying the applied load on the abrasion wheel, the rotation speed of the wheel, and test duration in the case of abrasion resistant materials. 


\section{References}

1. Gaier, J.R. (2007): “The Effects of Lunar Dust on EVA Systems During the Apollo Missions," NASA Glenn Research Center. NASA/TM-2005-213610/REV1.

2. Heiken, G.H., Vaniman, D.T., French, B.M. (1991): "LUNAR Sourcebook: A User's Guide to the Moon," Cambridge University Press and Lunar and Planetary Institute.

3. Taylor, L.A., Schmitt, H.H., Carrier, W.D. \& Nakagawa, M. (2005): "The Lunar Dust Problem: From Liability to Asset," AIAA 1st Space Exploration Conference: Continuing the Voyage of Discovery. Orlando, FL. AIAA-2005-2510.

4. Rickman, D. \& Street, K.W. (2008): "Expected Mechanical Characteristics of Lunar Dust: A Geological View," Proceedings of the Space Technology and Applications International Forum, Albuquerque, NM. AIP Conf. Proc., 969, 949-955.

5. Plescia, J. (2008): "Lunar Regolith Formation and Properties," Presentation, Lunar Regolith Community of Practice (LunRCoP) Webinar, 26 Feb 2008.

6. Kobrick, R.L., Klaus, D.M., and Street, K.W. (2009): "Developing Abrasion Test Standards for Evaluating Lunar Construction Materials," 39th ICES, Savannah, GA. SAE Technical Paper 2009-012377 [accepted for publication (2010) SAE Transactions Journal of Aerospace].

7. Kobrick, R.L., Street, K.W., Klaus, D.M., Greenberg, P.S., and Hyatt, M.J. (2008): "Developing Abrasion Testing Hardware to Evaluate Effects Caused by Lunar Dust on Construction Materials," 59th IAC, IAC-08-A3.2.INT3, Glasgow, UK.

8. Kobrick, R.L., Klaus, D.M., and Street, Jr., K.W. (2010, Submitted for Publication): "Validation of proposed metrics for two-body abrasion scratch test analysis standards," J. WEAR. Elsevier.

9. Kobrick, R.L., Klaus, D.M., and Street, Jr., K.W. (2010, Submitted for Publication): "Standardization of a volumetric displacement measurement for two-body abrasion scratch test data analysis," J. WEAR. Manuscript number: IH-6025. Elsevier.

10. ASTM B611 - 85 (2005): "Standard Test Method for Abrasive Wear Resistance of Cemented Carbides," ASTM International, West Conshohocken, PA, 2005, DOI: 10.1520/B0611-85R05, www.astm.org.

11. ASTM G65 (2004): "Standard Test Method for Measuring Abrasion Using the Dry Sand/Rubber Wheel Apparatus," ASTM International, West Conshohocken, PA, 2005, DOI: 10.1520/G0065-04, www.astm.org.

12. ASTM G76 (2007): "Standard Test Method for Conducting Erosion Tests by Solid Particle Impingement Using Gas Jets," ASTM International, West Conshohocken, PA, 2005, DOI: 10.1520/G0076-07, www.astm.org.

13. Budinski, K.G. and Budinski, M.K. (2010): "Engineering Materials: Properties and Selection - 9th Edition," Columbus OH: Prentice Hall.

14. Cole, D.M., Taylor, L.A., Liu, Y., and Hopkins, M.A. (2010): "Grain-scale mechanical properties of lunar plagioclase and its simulant: Initial experimental findings and modeling implications," Earth \& Space 2010: Engineering, Science, Construction, and Operations in Challenging Environments. ASCE. pp. $74-83$. 



\section{Appendix A.-Summary of Data From Three-Body Abrasion Testing}

\begin{tabular}{llcc} 
& & \multicolumn{2}{c}{ Wear volume, $\mathrm{cm}^{3}$} \\
\cline { 3 - 4 } Material & \multicolumn{1}{c}{ Abrasive } & Mean & Std. Dev. (n) \\
\hline 6061 Al & JSC-1A-F & 0.0075 & $0.0001(3)$ \\
1018 Steel & JSC-1A-F & 0.0005 & $0.0004(3)$ \\
1045 Steel & JSC-1A-F & 0.0002 & $0.0002(3)$ \\
PMMA & JSC-1A-F & 0.0546 & $0.0106(3)$ \\
\hline 6061 Al & Silica & 0.0106 & $0.0006(4)$ \\
1018 Steel & Silica & 0.0049 & $0.0004(4)$ \\
1045 Steel & Silica & 0.0014 & $0.0003(4)$ \\
PMMA & Silica & 0.0399 & $0.0027(4)$ \\
\hline 6061 Al & Alumina & 0.0156 & $0.0011(4)$ \\
1018 Steel & Alumina & 0.0075 & $0.0010(4)$ \\
1045 Steel & Alumina & 0.0053 & $0.0007(4)$ \\
PMMA & Alumina & 0.1274 & $0.0017(4)$ \\
\hline 6061 Al & JSC-1A-F $<25 \mu \mathrm{m}$ & 0.0039 & $0.0002(3)$ \\
1018 Steel & JSC-1A-F $<25 \mu \mathrm{m}$ & 0.0007 & $0.0000(3)$ \\
1045 Steel & JSC-1A-F $<25 \mu \mathrm{m}$ & 0.0002 & $0.0001(3)$ \\
PMMA & JSC-1A-F $<25 \mu \mathrm{m}$ & 0.0515 & $0.0015(3)$ \\
\hline 6061 Al & NU-LHT-2M & 0.0126 & $0.0010(3)$ \\
1018 Steel & NU-LHT-2M & 0.0030 & $0.0006(3)$ \\
PMMA & NU-LHT-2M & 0.0604 & $0.0032(3)$ \\
\hline
\end{tabular}

${ }_{\mathrm{a}}=$ number of tests 


\begin{tabular}{|c|c|c|}
\hline \multicolumn{2}{|c|}{ REPORT DOCUMENTATION PAGE } & $\begin{array}{l}\text { Form Approved } \\
\text { OMB No. 0704-0188 }\end{array}$ \\
\hline \multicolumn{3}{|c|}{$\begin{array}{l}\text { The public reporting burden for this collection of information is estimated to average } 1 \text { hour per response, including the time for reviewing instructions, searching existing data sources, gathering and maintaining the } \\
\text { data needed, and completing and reviewing the collection of information. Send comments regarding this burden estimate or any other aspect of this collection of information, including suggestions for reducing this } \\
\text { burden, to Department of Defense, Washington Headquarters Services, Directorate for Information Operations and Reports (0704-0188), } 1215 \text { Jefferson Davis Highway, Suite } 1204 \text {, Arlington, VA } 22222-4302 \text {. } \\
\text { Respondents should be aware that notwithstanding any other provision of law, no person shall be subject to any penalty for failing to comply with a collection of information if it does not display a currently valid OMB } \\
\text { control number. } \\
\text { PLEASE DO NOT RETURN YOUR FORM TO THE ABOVE ADDRESS. }\end{array}$} \\
\hline $\begin{array}{l}\text { 1. REPORT DATE (DD-MM-YYYY) } \\
01-08-2010\end{array}$ & $\begin{array}{l}\text { 2. REPORT TYPE } \\
\text { Technical Memorandum }\end{array}$ & 3. DATES COVERED (From - To) \\
\hline \multirow{3}{*}{\multicolumn{2}{|c|}{$\begin{array}{l}\text { 4. TITLE AND SUBTITLE } \\
\text { Three-Body Abrasion Testing Using Lunar Dust Simulants } \\
\text { to Evaluate Surface System Materials }\end{array}$}} & 5a. CONTRACT NUMBER \\
\hline & & $\begin{array}{l}\text { 5b. GRANT NUMBER } \\
\text { NNX07AR55H }\end{array}$ \\
\hline & & 5c. PROGRAM ELEMENT NUMBER \\
\hline \multirow{3}{*}{\multicolumn{2}{|c|}{$\begin{array}{l}\text { 6. AUTHOR(S) } \\
\text { Kobrick, Ryan, L.; Budinski, Kenneth, G.; Street, Kenneth, W., Jr.; Klaus, David, M. }\end{array}$}} & 5d. PROJECT NUMBER \\
\hline & & 5e. TASK NUMBER \\
\hline & & $\begin{array}{l}\text { 5f. WORK UNIT NUMBER } \\
\text { WBS 936374.03.05.03.03 }\end{array}$ \\
\hline \multicolumn{2}{|c|}{$\begin{array}{l}\text { 7. PERFORMING ORGANIZATION NAME(S) AND ADDRESS(ES) } \\
\text { National Aeronautics and Space Administration } \\
\text { John H. Glenn Research Center at Lewis Field } \\
\text { Cleveland, Ohio 44135-3191 }\end{array}$} & $\begin{array}{l}\text { 8. PERFORMING ORGANIZATION } \\
\text { REPORT NUMBER } \\
\text { E-17408 }\end{array}$ \\
\hline \multirow{2}{*}{\multicolumn{2}{|c|}{$\begin{array}{l}\text { 9. SPONSORING/MONITORING AGENCY NAME(S) AND ADDRESS(ES) } \\
\text { National Aeronautics and Space Administration } \\
\text { Washington, DC 20546-0001 }\end{array}$}} & $\begin{array}{l}\text { 10. SPONSORING/MONITOR'S } \\
\text { ACRONYM(S) } \\
\text { NASA }\end{array}$ \\
\hline & & $\begin{array}{l}\text { 11. SPONSORING/MONITORING } \\
\text { REPORT NUMBER } \\
\text { NASA/TM-2010-216781 }\end{array}$ \\
\hline
\end{tabular}

\section{DISTRIBUTION/AVAILABILITY STATEMENT}

Unclassified-Unlimited

Subject Categories: 42 and 48

Available electronically at http://gltrs.grc.nasa.gov

This publication is available from the NASA Center for AeroSpace Information, 443-757-5802

\section{SUPPLEMENTARY NOTES}

\section{ABSTRACT}

Numerous unexpected operational issues relating to the abrasive nature of lunar dust, such as scratched visors and spacesuit pressure seal leaks, were encountered during the Apollo missions. To avoid reoccurrence of these unexpected detrimental equipment problems on future missions to the Moon, a series of two- and three-body abrasion tests were developed and conducted in order to begin rigorously characterizing the effect of lunar dust abrasiveness on candidate surface system materials. Two-body scratch tests were initially performed to examine fundamental interactions of a single particle on a flat surface. These simple and robust tests were used to establish standardized measurement techniques for quantifying controlled volumetric wear. Subsequent efforts described in the paper involved three-body abrasion testing designed to be more

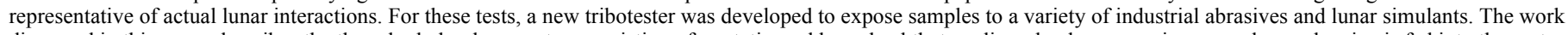

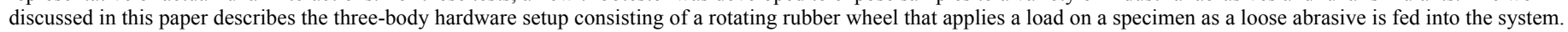
The test methodology is based on ASTM International (ASTM) B611, except it does not mix water with the abrasive. All tests were run under identical conditions. Abraded material specimens included poly(methyl methacrylate) (PMMA), hardened 1045 steel, 6061-T6 aluminum (Al) and 1018 steel. Abrasives included lunar mare simulant JSC1A-F (nominal size distribution), sieved JSC-1A-F ( $<25 \mu \mathrm{m}$ particle diameter), lunar highland simulant NU-LHT-2M, alumina (average diameter of 50 $\mu \mathrm{m}$ used per ASTM G76), and silica (50/70 mesh used per ASTM G65). The measured mass loss from each specimen was converted using standard densities to determine total wear volume in

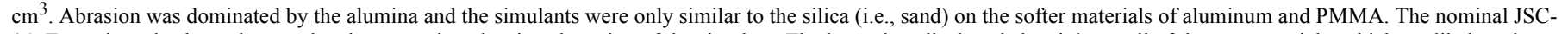

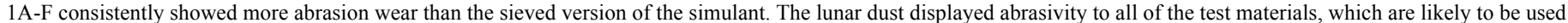

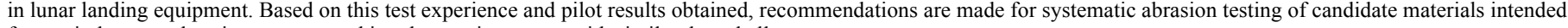
for use in lunar exploration systems and in other environments with similar dust challenges.

15. SUBJECT TERMS

Abrasion; Lunar exploration

\begin{tabular}{|c|c|c|c|c|c|}
\hline \multicolumn{3}{|c|}{ 16. SECURITY CLASSIFICATION OF: } & \multirow{2}{*}{$\begin{array}{l}\text { 17. LIMITATION OF } \\
\text { ABSTRACT } \\
\text { UU }\end{array}$} & \multirow{2}{*}{$\begin{array}{l}\text { 18. NUMBER } \\
\text { OF } \\
\text { PAGES } \\
14\end{array}$} & \multirow{2}{*}{$\begin{array}{l}\text { 19a. NAME OF RESPONSIBLE PERSON } \\
\text { STI Help Desk (email:help@sti.nasa.gov) } \\
\text { 19b. TELEPHONE NUMBER (include area code) } \\
\text { 443-757-5802 }\end{array}$} \\
\hline $\begin{array}{l}\text { a. REPORT } \\
\text { U }\end{array}$ & $\begin{array}{l}\text { b. ABSTRACT } \\
\text { U }\end{array}$ & $\begin{array}{l}\text { c. THIS } \\
\text { PAGE } \\
\text { U }\end{array}$ & & & \\
\hline
\end{tabular}



